\title{
Housing the Workforce Following the Canterbury Earthquakes in New Zealand
}

\author{
Y. Chang-Richards and S. Wilkinson \\ Department of Civil and Environmental Engineering, University of Auckland \\ E. Seville and D. Brunsdon \\ Resilient Organisations Research Programme, New Zealand
}

\begin{abstract}
Temporary housing following a large-scale disaster has a positive effect on household welfare and community recovery. Following the 2010 and 2011 Canterbury earthquakes, a shortage of temporary accommodation created barriers for the outside construction workforce to engage in repairs and rebuild in Christchurch. This study investigates the impacts of housing shortages for the overall recovery and the strategies adopted by both households and the workforce in the building industry. Findings suggest that the interplay among the industry strategies and household strategies for securing housing determines the magnitude and scope of economy-wide inflation. One unfortunate consequence of these industry strategies is that the pressures of resource shortages are likely to transit from the construction sector to quake-affected households. These findings have implications on the nature and design of pre and postdisaster planning programs in order to reduce the impacts of housing issues on household welfare and, at the same time, to the meet the needs of the construction sector if the scheduled rebuild works are to be achieved.
\end{abstract}

\section{INTRODUCTION}

Temporary housing plays a critical role in the aftermath of a major disaster as it offers victims a safe transition to normal life (Felix, Branco, \& Feio, 2013; Johnson, 2007b; Peacock, Dash, \& Zhang, 2007). For countries or regions where there is a limited resource pool and external resources need to be brought in to undertake large-scale disaster reconstruction, temporary housing for outside workers is a key component of the construction industry's capability. According to Comerio (1997), a housing crisis will result when there is a lack of housing stocks available for disaster victims. This crisis is likely to be compounded by construction workers who compete with locals for limited housing stock, putting lower-income people at risk of displacement (Plyer, Ortiz, Turner, Pettit, 2009).

In rebuilding after a devastating disaster, affected people need to relocate to temporary places while their houses are under repair or are rebuilt. To meet these demands, governments in every country after a major disaster tend to establish disparate temporary housing assistance programmes (Iwasa, Hasegawa, Shinkai, Shinozaki, Yasutake, \& Kobayashi, 2012). Commonly designed to serve a variety of demographic and socioeconomic settings, these temporary houses provide a range of substantive functions as the affected population recovers from disasters. They differ depending on the construction type and scale of capacity (Felix et al., 2013; Johnson, 2007a; Ritchie \& Tierney, 2011); financial mechanisms, especially regarding the sources and flow of funds for both erection and maintenance (Jones \& Wilson, 2009; Maly \& Kondo, 2013); organisational design (Johnson, 2007b); and the characteristics of the population they serve (Harasawa, Tanimoto, Kami, Oikawa, Kanazawa, \& Komatsu, 2012; Iwasa et al., 2012; Rafieian \& Asgary, 2013).

The provision of temporary housing for disasteraffected populations, however, only provides a onedimensional view of how disaster recovery can be affected as a result of this solution. In a more developed country, it is often the case that a decrease in housing stock will lead households to look for what accommodation is available. On the other hand, large-scale reconstruction may induce the outside workforce to come to the disasteraffected areas during the period of rebuild or even longer (Chang, Wilkinson, Potangaroa, \& Seville, 2011). Those workers may pursue affordable accommodation with reasonable living conditions and drive the housing demand. In such a situation, the local capacity for housing may become a critical factor attracting needed personnel from outside the disaster zone and affecting the speed and cost of reconstruction in the region (Chang-Richards, Wilkinson, Seville, \& Brunsdon, 2013).

The large-scale rebuilding effort in New Orleans, for instance, increased demands for construction 
workers which were already in short supply because of strong home-building activity around the rest of the country (National Association of Home Builders , 2005). In a survey of construction workers rebuilding New Orleans, Fletcher, Pham, Stover, and Vinck (2007) found that $70 \%$ of surveyed workers were U.S. citizens and most of them came from other states such as Texas and Florida. The remainder were from other countries, including Mexico, Honduras, and El Salvador; most were Latino. To a varied degree, high demand of rental properties for the reconstruction workforce had contributed to local rent escalation, with many displaced households and low-income renters being priced out of the market (Plyer, Ortiz, \& Pettit, 2009).

The problems and issues regarding temporary housing for reconstruction workers also surfaced in Christchurch after the 2010 and 2011 earthquake events. Based on a study in Christchurch, this paper considers the impacts of housing shortages for the overall recovery and the strategies adopted by both households and the workforce in the building industry. Specifically, market-level investigation is focused on understanding the effects of (1) workforce immigration patterns, (2) nature and availability of housing, (3) existence and impact of postearthquake policies, and (4) interplay between the industry strategies and household strategies for securing available housing units.

This work is significant for three reasons. First, it seeks recovery lessons for future catastrophic earthquakes by studying insurance-led earthquake recovery in New Zealand. Second, it focuses on a spectrum of housing needs postdisaster which is beyond the household-level investigations existing in most literature. Third, it complements previous studies on temporary housing by examining the impact of housing shortages on the overall recovery and reconstruction. This research presents evidence from both construction organisations and accommodation suppliers in order to gain insights into the complexity of housing needs and how they interact and respond in a post-large disaster situation.

\section{HOUSING NEEDS FOLLOWING THE 2010, 2011 EARTHQUAKES IN CHRISTCHURCH}

A sequence of large earthquakes struck the Canterbury region of New Zealand in late 2010 and 2011. The two major ones were a 7.1 magnitude earthquake that hit west of Christchurch on September 4, 2010 and the deadly 6.3 magnitude earthquake on February 22, 2011. The second quake took 185 lives and caused substantial destruction of buildings, widespread land damage, and rock falls. Over 150,000 homes, about three quarters of Christchurch's housing stock, sustained some damage from the earthquakes. Some areas of Christchurch have been declared not suitable for rebuilding, affecting more than 7,800 residential properties. The total number of individual building, land, and contents claims received exceeded 600,000 (Earthquake Commission, 2012).

The biggest challenge faced by Christchurch as a result of the earthquakes is the changed residential land and the requirement for substantial land use reviews and zoning across the city. The government announced on June 23, 2011 that all land in greater Christchurch and in the Waimakariri District had been zoned into four residential zones-red (no rebuilding allowed), orange and white (further assessment needed), and green (rebuilding allowed) - based on geotechnical assessment. More than 7,800 property owners in the residential red zone were offered a buy-out package by the government to leave their uninhabitable houses. Houses in the green zone were also subdivided into three technical categories: TC1 (grey), TC2 (yellow) and TC3 (blue). In these subzones, more than 10,000 homes were assessed as in TC3 and required substantial foundation work before the houses would be considered safe for living.

Given the large-scale housing damage and in the context of other residential demand, there is a need for a range of affordable housing options:

- Non-red zone residents selling existing homes to red zone residents;

- Non-red zone residents opting to build elsewhere because of constraints on rebuilding on their existing properties;

- Accommodation for recovery workers; and

- Short-term accommodation needs of existing residents during the repair or rebuild of their homes.

Recognising these housing challenges, the government established three Temporary Villages and developed about 40 permanent units to fill the gap of unmet housing needs for displaced residents. Housing New Zealand initiated a progressive approach to rebuilding quake-damaged social housing properties in the eastern suburbs. Christchurch City Council fast tracked the repairs of its state housing for lower-income residents. Despite these efforts, the rental market still failed to meet the needs of other groups of people who sought affordable accommodation. The increase in the average weekly private rent in several Christchurch suburbs was $20 \%$ or more for the 3 months ending January 2013, compared to the same period the previous year (Ministry of Business, Innovation and Employment [MBIE], 2013b]. Some areas, such as "Inner North" and "North West," recorded above- 
average rent increases of $39 \%$ and $32 \%$, respectively (MBIE, 2013a).

The temporary accommodation issue has become prominent as competing demands emerge between the reconstruction workforce, who are from outside Christchurch, and displaced residents, including redzone residents and those whose houses are subject to repairs. Demand for housing from construction workers, however, is likely to compound the shortage of houses available to residents displaced by the earthquakes. Against this backdrop, this paper aims to investigate the housing needs posed by the construction workforce involved in postearthquake reconstruction in order to improve the understanding of housing issues postdisaster.

\section{RESEARCH METHODS}

Empirically, this research is based on the case study of postdisaster recovery and reconstruction in Christchurch following the 2010 and 2011 earthquakes. According to Leedy and Ormrod (2010), a case study is especially suitable for learning more about a little known or poorly understood situation. The case study method in this research can therefore help add to the understanding of this topic. Methods for data collection included participatory observations, a questionnaire survey, interviews, and document studies (Table 1).

Table 1. Summary of research data collection methods

\begin{tabular}{|c|c|}
\hline Objectives & Participants \\
\hline $\begin{array}{l}\text { 1. To understand } \\
\text { the patterns of } \\
\text { labor influx post- } \\
\text { earthquake }\end{array}$ & $\begin{array}{l}\text { May 2012, November and December } 2012 \\
33 \text { interview participants from: } \\
3 \text { design organisations } \\
5 \text { structural engineering consultancies } \\
1 \text { large geotechnical engineering company } \\
5 \text { construction contractors and builders } \\
5 \text { Project Management Offices (PMOs) } \\
1 \text { Building Industry Association } \\
2 \text { Government departments (Building and } \\
\text { Housing Group \& Labour Group in MBIE) }\end{array}$ \\
\hline \multirow{2}{*}{$\begin{array}{l}\text { 2. To capture the } \\
\text { housing needs of } \\
\text { those out-of-town } \\
\text { workers for } \\
\text { earthquake } \\
\text { repairs and } \\
\text { rebuild }\end{array}$} & $\begin{array}{l}\text { April and May } 2013 \\
\text { Online questionnaire survey of } \mathbf{3 8} \\
\text { participants: } \\
26 \text { motel owners/operators } \\
6 \text { operators of motor camps and holiday } \\
\text { parks } \\
6 \text { property managers }\end{array}$ \\
\hline & $\begin{array}{l}\text { May } 2013 \\
\text { Semi-structured interviews with } \mathbf{2 9} \\
\text { selected survey participants: } \\
3 \text { holiday parks owners/operators } \\
2 \text { Bed \& Breakfast owners } \\
1 \text { Hotel operator } \\
19 \text { Motel owners/operators } \\
2 \text { rental property managers } \\
2 \text { home-stay managers }\end{array}$ \\
\hline
\end{tabular}

To understand the patterns of labor influx postearthquake, primary data was collected through field observations and in-depth, semistructured interviews with 33 participants from 22 construction organisations and 2 recovery agencies. The interviews and field observations were conducted in Christchurch in May 2012, followed by a second round of interviews between November and December 2012.

To capture the housing needs and options of those out-of-town workers, an online questionnaire survey of Christchurch Motel Association and property managers was initiated between April and May 2013. Of a sample of 128 accommodation owners/operators and property managers, 38 responded to the survey with a response rate of approximately $30 \%$. Detailed interviews with 29 selected accommodation owners/operators followed in May to supplement questionnaire findings. Document studies were also undertaken, including reviewing the recovery strategy and plans of Christchurch, local newspapers (The Press), and publications of the recovery agencies.

\section{RESEARCH RESULTS}

A shortage of temporary accommodation has become a real concern for many construction organisations engaged in repairs and rebuildin in Christchurch. This study provides an initial estimate of accommodation needs of the construction sector. The housing needs posed by out-of-town workers were reported by interviewed organisations and can be summarised into three groups. First are the workers who were temporarily relocated from other offices across New Zealand. These workers tended to stay in commercial beds. It includes short- to medium-term apartments, townhouses, motels, hotels, and bed and breakfasts.

The second category includes workers who were on longer-term relocation for more than six months. According to most interviewed companies, these workers aim for places with cooking facilities and access to workplace and community services. However, these accommodation needs were met by the private rental market and company-purchased houses. The third category includes construction workers who were considered as permanent migrants. Many of workers were recruited from overseas, and some of those who relocated from other parts of New Zealand had an expectation to live in Christchurch on a potential permanent basis. As reported by the construction organisations, the needs of these people are generally more complex. A short period of temporary solutions was often provided by companies until workers found their own housing. Therefore, securing an accommodation for 
these people takes longer before integration into the community is possible.

Some engineering consultants reported ongoing issues sourcing people with high skill levels. Young engineers and mature project management skills from Europe continue to be the largest inbound demographic group involved with the rebuild (Table 2). Some construction organisations faced difficulties with immigration issues and housing their incoming workforces. At the same time, the inflationary impact which flowed through to higher property rents made attracting tradespeople from other parts of New Zealand more difficult.

From surveying the commercial accommodation providers, Figure 1 presents a snapshot of commercial accommodation capacity taken by construction workers who were involved with the Canterbury rebuild, homeowners, tourists, and others in 2011, 2012, and 2013.

The survey shows that following the September 2010 earthquake, construction workers, along with displaced home owners who were having emergency repairs or permanent repairs and rebuilds, became a large force of guests taking up half of the capacity in motels. The most significant increase in the number of displaced homeowners staying in motels since 2012 could reflect a combination of a decrease of rental supply, increasing demand from residents leaving the red zone, and increased insurance residential repairs in the same period.

Table 2. Demographic features of migrant workers for rebuild in Christchurch

\begin{tabular}{l|l|l}
\hline Characteristic & Engineers & $\begin{array}{l}\text { Building control } \\
\text { professionals }\end{array}$ \\
\hline Origin & $\begin{array}{l}\text { Earthquake-prone } \\
\text { countries - the U.S. } \\
\text { Italy, Spain, Chile }\end{array}$ & $\begin{array}{l}\text { Europe, Australia, } \\
\text { the U.S. }\end{array}$ \\
\hline Age cohort & $25-35$ & $30-50$ \\
\hline $\begin{array}{l}\text { Work } \\
\text { experience }\end{array}$ & $\begin{array}{l}\text { New graduates or } \\
\text { more than 2 years' } \\
\text { experience }\end{array}$ & $\begin{array}{l}\text { At least 5-10 years } \\
\text { plus experience }\end{array}$ \\
\hline
\end{tabular}

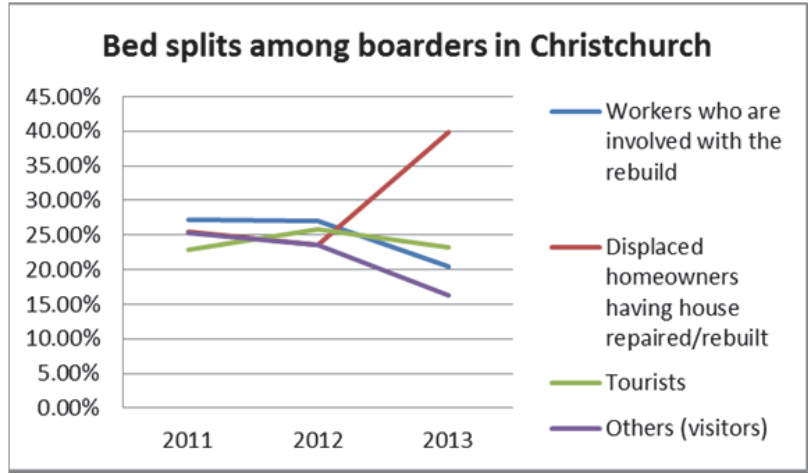

Figure 1. Commercial accommodation capacity among boarders in Christchurch
Interviews with accommodation providers also identified a number of trends that are likely to drive demand for low-cost accommodation in the construction sector. The shortages of accommodation were most pronounced at the operative level of construction companies. Affordability and accessible space for parking work vehicles were reported by construction workers, particularly most builders and tradespeople, as the top two priorities when they looked for accommodation. As a result, construction workers have a strong preference for holiday parks, motor camps, and backpacker lodges as most allow for parking flexibility, and the rates are relatively cheaper compared to other commercial bed options.

\section{DISCUSSION AND IMPLICATIONS}

Christchurch city lacked a comprehensive approach to addressing housing needs across a spectrum of the population following the earthquakes. It appeared that the government agencies and housing authorities gave highest priority to rapid repairs of public housing. Existing housing assistance did not match the damage needs of earthquake events. The actual impacts of housing damage and the spill-over effects to other sectors will take time to discover and quantify (Hallegatte \& Ghil, 2008). Lower-income people were targeted for special attention after the disaster, but there was also a substantial need for coordinated assistance for construction workers to support the postdisaster recovery and reconstruction. As housing issues are economywide, it is therefore vital that any housing strategy enables all agencies and accommodation providers to work together to address housing-related issues.

In major disasters, low-cost rental housing constitutes a substantial portion of the affected housing stock (Comerio, 1997; Edgington, 2010; Tafti \& Tomlinson, 2013). This has been the case in Christchurch following the earthquakes. Both temporary and permanent rental properties were mostly sought by both earthquake-displaced home owners and out-of-town workers. Additionally, this study shows that there is also a lack of large, private, low-cost accommodation providers in Christchurch which are most needed by builders and construction tradespeople. There is a need for a systematic review of the learnings from overseas experience on the model of temporary accommodation provisions for construction workers and how it was integrated into and balanced with assistance for disasterdisplaced residents.

Research findings also suggest that there is a strong tendency for commercial accommodation providers, such as motels, hotels, and lodging-type facilities, to absorb the workforce with capacities that were originally intended for tourists and visitors. There is 
also a strong tendency for recovery agencies and insurance companies to perceive the displacement as being an issue for households to solve, given the technical and financial assistance provided. However, a strong case can be made that it is such matters as lack of preimpact housing inventories (Comerio, 1993; Peacock et al., 2007), failure to recognize the correlation between disaster and housing (Brezar, 2005), inadequate cooperation among insurance companies (Chang-Richards et al., 2013), and other organisational and community-level factors (Levine et al., 2007) which contribute to the problem of housing shortages across a spectrum of the needy.

A lack of transitional accommodation for construction workers had forced workers to rent any houses available on the private market, consequently reducing availability for Christchurch residents. However, trade workers' ability to pay above-market rent to secure rental accommodation exacerbated inflation in the housing market. In line with price responsiveness of the housing market (Whitehead, 1999) and natural disaster economies (Hallegatte \& Ghil, 2008; Hallegatte \& Przyluski, 2010), the research shows that the impact of construction workers monopolising available accommodation has a negative impact on the entire housing market and tourism industry. The provision of accommodation for both workers and displaced residents should be considered as being equally important. This study suggests that the government, together with local council, work with the existing operators to facilitate an expansion of their facilities to meet demand from both displaced residents and workers required for repairs.

\section{CONCLUSIONS}

An important lesson from a large-scale disaster is that the significant level of damage to residential housing, the acute labour demand to undertake repairs, the general lack of temporary accommodation, and the forecasted higher demand for skills for rebuilding could, if managed poorly, lead to adverse social and economic consequences for local industry and communities. By examining the workforce accommodation issues following the Christchurch earthquakes, this paper raises the importance of the often overlooked yet critical issue after large disasters, relating to the processes of disaster recovery as well as its outcomes.

The study shows that provision of temporary accommodation for construction workers involved in repairs and rebuilding has a crucial role to play for recovery, particularly if housing assistance is integrated into the economic response. For a region which needs to rely on massive labor influx for rebuilding, temporary housing is critical to the construction industry capability. Future detailed case studies of construction organisations are needed to provide insights into how hiring strategies across the construction industry and their strategies for housing the workforce will change the landscape of housing needs in Christchurch.

According to official projections, there will be an additional 17,000 workers needed to meet demand at the height of the rebuilding activity in late 2014 . Flowing on from the rebuild, another 15,000 workers will be needed in supporting roles and sectors, including administration, law, accounting, retail, accommodation, and services (MBIE, 2013a). Additional government and industry efforts in supporting interim housing solutions is needed if the projected increase in rebuilding work in 2014 and 2015 is to be achieved. Also, to reduce the impact of housing shortages at the speed and cost of reconstruction, recovery agencies need to integrate housing needs of out-of-town workers with those of displaced households as part of the longer-term housing recovery and economic development strategy.

\section{ACKNOWLEDGMENTS}

As part of the "Resilient Organisations" research programme, this research was supported by the Building Research Association of New Zealand (BRANZ) and the New Zealand Natural Hazards Research Platform (NHRP). The authors wish to thank the New Zealand Construction Industry Council (NZCIC), the Motel Association of New Zealand (MANZ), and the research project Industry Advisory Committee for their assistance in data collection for this study.

\section{REFERENCES}

Chang, Y., Wilkinson, S., Potangaroa, R., \& Seville, E. (2011). Donor-driven resource procurement for post-disaster reconstruction: Constraints and actions. Habitat International, 35(2), 199-205. http://dx.doi.org/10.1016/j.habitatint.2010.08.003

Chang-Richards, Y., Wilkinson, S., Seville, E., \& Brunsdon, D. (2013, February). Myths and realities of reconstruction workers' accommodation. Auckland, NZ: Resilient Organisations.

Comerio, M. C. (1997). Housing issues after disasters. Journal of Contingencies and Crisis Management, 5(3), 166-178. http://dx.doi.org/ 10.1111/1468-5973.00052

Earthquake Commission. (2012). Briefing to the incoming minister, December 2011. Retrieved from http://www.eqc.govt.nz/about-eqc/people/briefingminister-2011

Felix, D., Branco, J. M., \& Feio, A. (2013). Temporary housing after disasters: A state of the art survey. 
Habitat International, 40, 136-141. http://dx.doi. org/10.1016/j.habitatint.2013.03.006

Fletcher, L. E., Pham, P., Stover, E., \& Vinck, P. (2007). Latino workers and human rights in the aftermath of Hurricane Katrina. Berkeley Journal of Employment and Labor Law, 28, 107-162. http://scholarship.law.berkeley.edu/facpubs/639

Hallegatte, S., \& Ghil, M. (2008). Natural disasters impacting a macroeconomic model with endogenous dynamics. Ecological Economics, 68(1-2), 582-592. http://dx.doi.org/10.1016/ j.ecolecon.2008.05.022

Harasawa, K., Tanimoto, T., Kami, M., Oikawa, T., Kanazawa, Y., \& Komatsu, H. (2012). Health problems in the temporary housing in Fukushima. The Lancet, 379(9833), 2240-2241. http://dx.doi. org/10.1016/S0140-6736(12)60978-7

Iwasa, A., Hasegawa, T., Shinkai, S., Shinozaki, M., Yasutake, A., \& Kobayashi, K. (2012). A practical approach to temporary housing for disaster victims. Journal of Asian Architecture and Building Engineering, 11(1), 33-38. http://dx.doi.org/ 10.3130/jaabe.11.33

Johnson, C. (2007a). Impacts of prefabricated temporary housing after disasters: 1999 earthquakes in Turkey. Habitat International, 31(1), 36-52. http://dx.doi.org/10.1016/j.habitatint. 2006.03.002

Johnson, C. (2007b). Strategic planning for postdisaster temporary housing. Disasters, 31(4), 435458. http://dx.doi.org/10.1111/j.1467-7717.2007. 01018.x

Jones, A., \& Wilson, E. (2009). Developing a more viable disaster housing unit: A case study of the Mississippi Alternative Housing Program. Washington, D.C.: Federal Emergency Management Agency. Retrieved from http://www.fema.gov/mississippi-alternativehousing-pilot-program.

Leedy, P. D., \& Ormrod, J. E. (2010). Practical Research: Planning and Design (9th ed.). Merrill, $\mathrm{NJ}$ : Pearson Education, Inc.
Maly, E., \& Kondo, T. (2013). From temporary to permanent: Mississippi cottages after Hurricane Katrina. Journal of Disaster Research, 8(3), 495-507.

Ministry of Business, Innovation and Employment. (2013a). Housing pressures in Christchurch: $A$ summary of the evidence. Wellington, NZ: Ministry of Business, Innovation and Employment (MBIE).

Ministry of Business, Innovation and Employment. (2013b). Archived reports: Key Canterbury indicators. Retrieved from http://www.dbh.govt.nz/ key-indicator-reports-archive\#canterbury

National Association of Home Builders. (2005, September 15). Impact of Hurricane Katrina on the building industry. Retrieved from http://www.nahb. org/default.aspx

Peacock, W. G., Dash, N., \& Zhang, Y. (2007). Sheltering and housing recovery following disaster. In H. Rodríguez, E. L. Quarantelli, \& R. R. Dynes (Eds.), Handbook of disaster research (pp. 258274). New York, NY: Springer. http://dx.doi.org/ 10.1007/978-0-387-32353-4_15

Plyer, A., Ortiz, E., \& Pettit, K. (2009, October 13). Post-Katrina housing affordability challenges continue in 2008, worsening among Orleans Parish very low income renters. Retrieved from http://www.datacenterresearch.org/reports_analysis /housing-affordability/

Plyer, A., Ortiz, E., Turner, M. A., \& Pettit, K. L. S. (2009, November 12). Housing production needs: Three scenarios for New Orleans. Retrieved from http://www.datacenterresearch.org/reports_analysis /housing-production-scenarios/

Rafieian, M., \& Asgary, A. (2013). Impacts of temporary housing on housing reconstruction after the Bam earthquake. Disaster Prevention and Management, 22(1), 63-74. http://dx.doi.org/ 10.1108/09653561311301989

Ritchie, L. A., \& Tierney, K. (2011). Temporary housing planning and early implementation in the 12 January 2010 Haiti earthquake. Earthquake Spectra, 27(S1), S487-S507. http://dx.doi.org/ 10.1193/1.3637637 